\title{
Spatiotemporal variability in Terminos Lagoon (Mexico) waters during the 2009-2010 drought reveals upcoming trophic status shift in response to climate change
}

\author{
Renaud Fichez ${ }^{1}$ (1) $\cdot$ Carlos Linares $^{2} \cdot$ Sandrine Chifflet $^{1} \cdot$ Pascal Conan $^{3} \cdot$ Adolfo Contreras Ruiz Esparza $^{4}$. \\ Lionel Denis ${ }^{5}$. Pascal Douillet ${ }^{1}$. Christian Grenz ${ }^{1}$ - Jean-François Ghiglione ${ }^{3}$. Francisco Gutiérrez Mendieta ${ }^{6}$. \\ Montserrat Origel-Moreno ${ }^{1} \cdot$ Alain Muñoz Caravaca ${ }^{7}$. Mireille Pujo-Pay ${ }^{3} \cdot$ Jorge Zavala-Hidalgo $^{4}$
}

Received: 8 March 2018 / Accepted: 11 May 2019

\begin{abstract}
The 2009-2010 El Niño was accompanied by a severe drought strongly impacting Mexico as well as Central America, the Caribbean, and the southern USA. The present work aims at assessing how such a major climatic event impacted the hydrological typology of transitional waters in Terminos Lagoon, one of the largest shallow tropical lagoons fringing the Gulf of Mexico. Spatiotemporal inter-comparison of hydrological conditions was conducted by pairing a reference multiparametric dataset (14 hydrological parameters versus 34 sampling stations) averaged over the October 2008 to July 2010 period with each sampling occurrence dataset and running Principal Component Analyses (PCA), setting the reference-survey dataset as active variables and each sampling occurrence dataset as non-active (supplementary) variables. It revealed that the exceptional deficit in freshwater supply to the lagoon during the 2009-2010 El Niño drastically reduced hydrological diversity and lowered the trophic status of the lagoon. Short-term shifts in environmental status are common in transitional waters and responsible for temporary shifts in community structure but climate change projections show a significant long-term decrease in the freshwater discharge at the regional scale that will impact Terminos Lagoon as well as other coastal lagoons of Mexico and Central America. When combined with sea level rise, such a decrease will result in a long-term shift in hydrological conditions with a subsequent increase in salinity and a decrease in the diversity of environmental conditions affecting trophic status, will have a long-term impact on the biota.
\end{abstract}

Keywords Coastal lagoon $\cdot$ Hydrology $\cdot$ Trophic status $\cdot$ El Niño $\cdot$ Global change $\cdot$ Climate change, Mexico

Editor: Erika Coppola

Renaud Fichez

renaud.fichez@ird.fr

Carlos Linares

Carlos.Garcia.Linares@usherbrooke.ca

Sandrine Chifflet

sandrine.chifflet@mio.osupytheas.fr

Pascal Conan

pascal.conan@obs-banyuls.fr

Adolfo Contreras Ruiz Esparza

adolfo.contreras@atmosfera.unam.mx

Lionel Denis

lionel.denis@univ-lille1.fr

Pascal Douillet

pascal.douillet@mio.osupytheas.fr

\author{
Christian Grenz \\ christian.grenz@mio.osupytheas.fr \\ Jean-François Ghiglione \\ jean-francois.ghiglione@ obs-banyuls.fr \\ Francisco Gutiérrez Mendieta \\ fgm@xanum.uam.mx \\ Montserrat Origel-Moreno \\ origel.montserrat@gmail.com \\ Alain Muñoz Caravaca \\ alain@gestion.ceac.cu \\ Mireille Pujo-Pay \\ mireille.pujo-pay@obs-banyuls.fr \\ Jorge Zavala-Hidalgo \\ jzavala@atmosfera.unam.mx
}

Extended author information available on the last page of the article 


\section{Introduction}

Littoral regions accommodate a broad range of coastal systems with heterogeneous water bodies often referred to as "transitional waters" characterized by strong variability in salinity as well as in most environmental parameters of natural or anthropogenic origin which are driven by the balance between marine and freshwater inputs (Elliott and McLusky 2002; McLusky and Elliott 2007). Response of transitional waters to ongoing climate change has risen to the highest level of economic and political priority, resulting in a growing demand for the accurate scientific expertise essential for the definition; implementation; and control of ecologically, socially, and economically effective management plans. This is especially true in the Terminos Lagoon area, on the southern Gulf coast of Mexico, which has been singled out as being vulnerable to climate change (Magrin et al. 2007), potentially exposed by the end of the twenty-first century to a drastic decrease in river discharge from the Usumacinta-Grijalva River (Kemp et al. 2016), and subject to general sea level rise in the range 0.5 to $1 \mathrm{~m}$ (Magrin et al. 2007; Rahmstorf 2012). Here, as in all other transitional water systems, a proper assessment of spatiotemporal variability must be considered as a prerequisite to the scientific establishment of cause to effect relationships between global change and shifts in environmental conditions. However, spatiotemporal variability issues have often been overlooked in environmental studies, raising the risk of drawing insufficiently supported scientific interpretation and of misguiding environmental policies toward inefficient management action plans (Lucena-Moya et al. 2012). Extracting comprehensive information from multiparametric environmental databases remains a challenge and environmetric approaches based on multivariate data ordination have been proven to be a rigorous and integrative way of assessing spatial and temporal variability of transitional waters (Fichez et al. 2010; Shin et al. 2013). The approach developed in the present study specifically focuses on the physicochemical and biogeochemical indicators of water quality that are commonly measured in environmental status assessments. Establishing a multiparametric characterization of transitional waters has been identified as a key integrative diagnostic approach that is still strongly lacking in environmental management (Poikane et al. 2014). Recent concerns about delineating environmental status categories for transitional waters have largely focused on intercomparison between distinct systems, to the detriment of the preliminary assessment of internal spatiotemporal variability (Larned 1998; Liston et al. 1992; Muslim and Jones 2003; Lucena-Moya et al. 2012), with the most in-depth studies often being circumscribed to gray literature reports (Haynes et al. 2001; Furnas 2003). As a consequence, and due to the complex synergistic impacts of ongoing changes in climate conditions and local anthropogenic drivers, there is a strong risk of hastily drawing cause-and- effect relationship, regardless of what spatiotemporal variability has to teach us about the flexibility of tropical transitional systems and about the most probable scenarios at stake in terms of environmental response to global change. Such a lack of information on the distribution and temporal variability of environmental parameters is especially critical for coastal tropical systems of emerging and developing countries where the potential threat of global change is increasingly acknowledged as a key parameter detrimentally impacting sustainable development. This is even more salient for the Mesoamerican region (Central America and Southern Mexico), which is considered to be the most prominent tropical climate change hotspot worldwide (Giorgi 2006) and which is increasingly vulnerable to extreme climatic events (Hidalgo et al. 2013; Vázquez-González et al. 2014).

The present study was conducted on the very large and shallow coastal Terminos Lagoon during a time period including the 2009-2010 El Niño Southern Oscillation positive anomaly when Mexico experienced the most severe drought since 1941 (Baringer et al. 2010). Its objectives, based on a 2year hydrological survey, aimed to (i) apply a data treatment allowing for temporal intercomparison of typology approaches; (ii) analyze what such an intercomparison could reveal in terms of seasonal cycling and climate change in the specific context of the severe 2009-2010 El Niño-related drought period; and (iii) assess potential long-term environmental alteration in Terminos Lagoon in the context of climate change projection scenarios.

\section{Material and methods}

\section{Study site and environmental conditions}

The selection of Terminos Lagoon as a focus site for the study of tropical coastal lagoon transitional waters arose logically from its exceptional status as one of the largest shallow systems in the Gulf of Mexico, where conservation policies conflicted with anthropogenic pressure (Grenz et al. 2017). Moreover, Terminos Lagoon benefited from a significant scientific background and has been the recent object of renewed interest from the scientific community leading to its selection as a "pilot site" within the framework of the Global Environment Facility (GEF) Program on the Gulf of Mexico-Large Marine Ecosystem (GoM-LME) (García-Ríos et al. 2013). Terminos Lagoon (Fig. 1) is located on the southern coast of the Gulf of Mexico in the Mexican state of Campeche and stretches over a surface of $1936 \mathrm{~km}^{2}$ with an average depth of only $2.4 \mathrm{~m}$ yielding a total water volume of $4.65 \mathrm{~km}^{3}$ (Contreras Ruiz Esparza et al. 2014). Climate categories shift from tropical wet and dry in the lowlands to tropical rainforest in the highlands. There are three distinct seasonal periods throughout the year: a relatively dry season from 


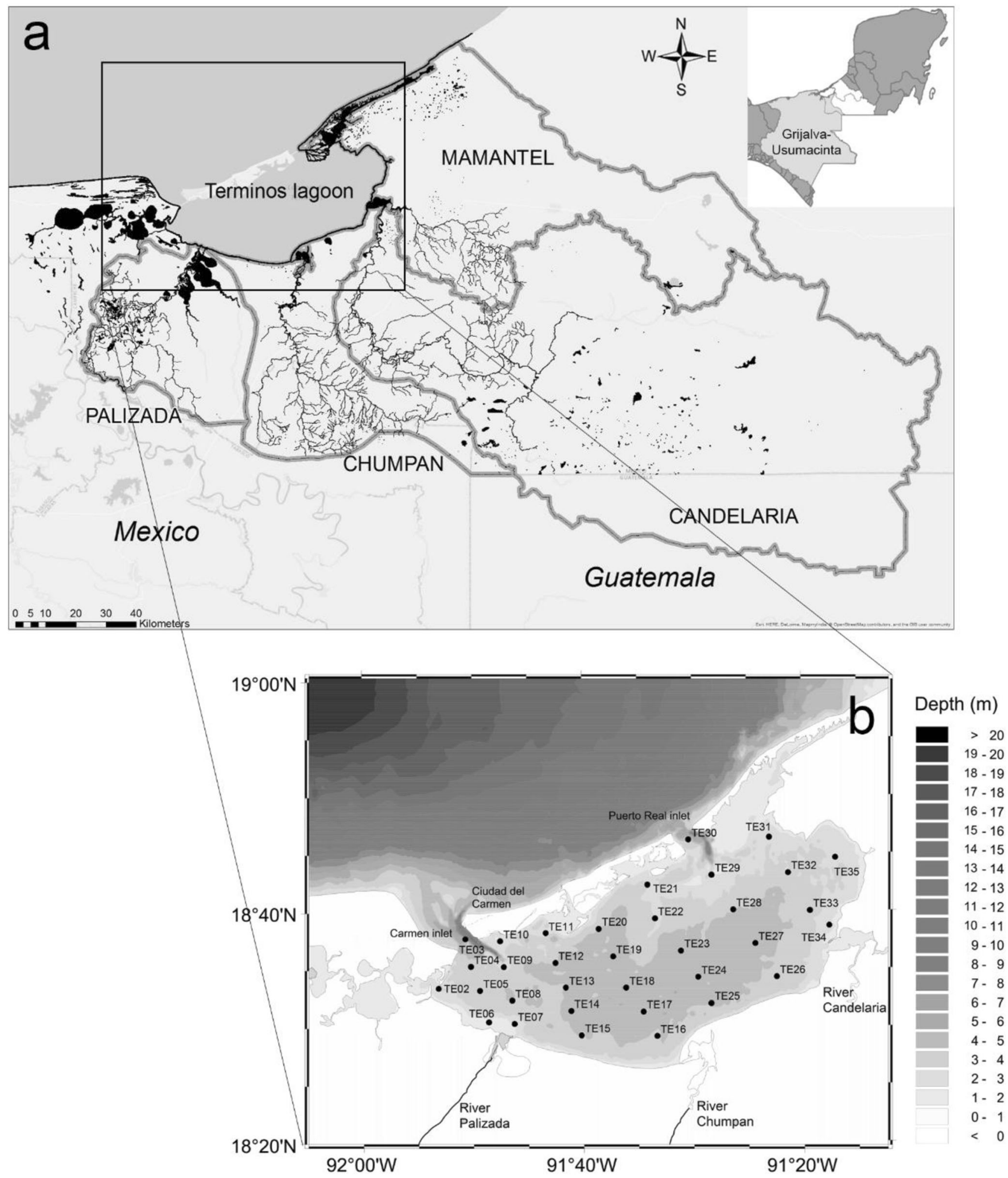

Fig. 1 a Terminos Lagoon location and surrounding watershed basins contributing to freshwater inputs keeping in mind that regardless of its watershed surface, roughly $10 \%$ of the Usumacinta River discharge flows through the Palizada River contributing to circa $90 \%$ of the freshwater inputs to the lagoon; and $\mathbf{b}$ bathymetry of Terminos Lagoon with location of the 34 sampling stations

Inland, Terminos Lagoon is surrounded by two very distinct geologic provinces. Eastward stretches the Yucatan Peninsula, 
characterized by low rainfall and a porous calcareous basement. This emerged carbonate platform has no river catchment so rainfall penetrates the porous basement, providing the water table with fresh water that finally seeps into the sea all along the coasts of the Peninsula. To the west and south of Terminos Lagoon are spread the lowlands of Tabasco and the highlands of Chiapas and Guatemala. Four river catchments directly discharge an average yearly volume of $11.96 \times 10^{9} \mathrm{~m}^{3} \mathrm{yr}^{-1}$ of freshwater into Terminos Lagoon (Robadue Jr et al. 2004), roughly amounting to 2.6 times its volume. Average yearly precipitation and evaporation of $1805 \mathrm{~mm} \mathrm{yr}^{-1}$ and $1512 \mathrm{~mm} \mathrm{yr}^{-1}$, respectively, result in a net rainfall of $293 \mathrm{~mm} \mathrm{yr}^{-1}$ (David and Kjerfve 1998; Espinal et al. 2007) and freshwater groundwater inputs to Terminos Lagoon have been averaged at $4 \times 10^{6} \mathrm{~m}^{3} \mathrm{yr}^{-1}$ (David 1999). The resulting freshwater input budget for Terminos Lagoon yielded a total net yearly input of $12.57 \times 10^{9} \mathrm{~m}^{3} \mathrm{yr}^{-1}$, of which river discharge, precipitation net input, and groundwater seepage accounted for $95.44 \%, 4.53 \%$, and $0.03 \%$, respectively, river discharge, therefore, remaining by far the main source of freshwater inputs to Terminos Lagoon (Fichez et al. 2017). The Chumpán River is the lowest contributor, with an average annual freshwater discharge of $0.6 \times 10^{9} \mathrm{~m}^{3} \mathrm{yr}^{-1}$ which passes through the Balchacah Lagoon before reaching Terminos Lagoon midway along its southern coast. The Candelaria River combines with the small Mamantel River to deliver a total of $2.26 \times 10^{9} \mathrm{~m}^{3} \mathrm{yr}^{-1}$ of freshwater to the lagoon through the so-called Pargos Estuary. Finally, the Palizada River discharges an average of $9.1 \times$ $10^{9} \mathrm{~m}^{3} \mathrm{yr}^{-1}$ of freshwater to Terminos Lagoon through the El Vapor, El Este, and Del Viento lagoons and the San Francisco and Chica openings, thereby accounting for more than two-thirds of the freshwater inputs to the lagoon. The Palizada is in fact a tributary of the Usumacinta River, which in turn is part of the intertwined Grijalva-Usumacinta basins that stretch over a total area of $112,550 \mathrm{~km}^{2}$ (Hudson et al. 2005). Receiving an average annual rainfall of $1709 \mathrm{~mm} \mathrm{yr}^{-1}$, the Usumacinta River discharges an average annual freshwater volume of $69 \times$ $10^{9} \mathrm{~m}^{3} \mathrm{yr}^{-1}$ to the Gulf of Mexico, of which a little less than one-tenth is diverted to the Terminos Lagoon through the Palizada River (Fichez et al. 2017). On its seaward side, the Terminos Lagoon is connected to the Gulf of Mexico by two straits - Carmen Strait on the western side (4 km long) and Puerto Real Strait on the eastern side (3.3 km long) - separated by Carmen Island, a carbonated sandbar $30 \mathrm{~km}$ long and $2.5 \mathrm{~km}$ wide. The lagoon's shallowness is disrupted only by channels located in the eastern part of each strait. Strong tidal currents generating lagoon inflow and outflow pass through those two straits that reach maximum depths of $19 \mathrm{~m}$ in Carmen Strait and $12 \mathrm{~m}$ in Puerto Real Strait.

\section{Sampling}

Sampling was conducted across a network of 34 stations (Fig. 1) during a total of nine sampling trips spanning a 2-year period from October 2008 to July 2010. Temperature, salinity (Sal), turbidity (Turb), oxygen saturation percentage $\left(\mathrm{O}_{2} \%\right)$, and in situ chlorophyll-a fluorescence (Fluo) profiles were obtained from a multiparametric profiler (SeaBird® SBE 19) equipped with additional sensors for turbidity (Seapoint ${ }^{\circledR}$ optical back scatter), dissolved oxygen (SeaBird® SBE 43), and chlorophyll-a in situ fluorescence (WETLabs ${ }^{\circledR}$ WETStar). Salinity was obtained with a precision of 0.001 . Calibrated back scattering turbidity sensors set-up in high turbidity mode provided NTU or nephelometric turbidity unit values with a precision of 0.1 NTU. As a general rule, it has been reported that backscattering was linearly correlated to suspended particulate matter concentrations below $10 \mathrm{~g} \mathrm{l}^{-1}$ with a general correspondence of $1 \mathrm{NTU}$ for $1 \mathrm{mg}$, with negligible variability between individual nephelometers but significant inter-site variability due to the very diverse optical properties and multi-modal particle size distribution of suspended particles in coastal lagoons (Ouillon et al. 2004). Chlorophyll-a in situ fluorescence is reported as arbitrary fluorescence units with a precision of 0.01 units. The combination of in situ fluorescence and chlorophyll-a analysis permitted to establish positive correlations between chlorophyll-a concentrations and in situ fluorescence for each sampling period. But the relationship changed from one sampling period to the next as other pigments - as well as particulate and dissolved organic matter generally abundant in transitional waters - interfered with the 460/695 $\mathrm{nm}$ excitation/emission wavelengths used to detect in situ chlorophyll-a (Zeng and Li 2015), thus preventing the establishment of a generic conversion rule.

Water was sampled using 5-1 Go-Flo bottles maintained horizontally at about $0.2 \mathrm{~m}$ below the surface. On board, water samples were treated following a three-step protocol: (1) as soon as the sampling bottle was retrieved, a 40-mL Schott ${ }^{\circledR}$ glass vial (previously washed with acid) was rinsed thrice with sampled water, filled, immediately injected with the reagent for ammonia $\left(\mathrm{NH}_{4}\right)$ determination, sealed, and stored in the dark for later fluorometric detection in the laboratory (Kérouel and Aminot 1997; Holmes et al. 1999); (2) two 30-mL and one $120-\mathrm{mL}$ Nalgene ${ }^{\circledR}$ plastic vials, all previously acidwashed, were rinsed thrice with sampled water, filled, and stored in a specifically dedicated and refrigerated ice cooler, to be later deep-frozen in the laboratory while awaiting analysis of dissolved inorganic and organic nutrients; and (3) a previously acid-washed 4-L Nalgene $®$ plastic container was rinsed thrice with sampled water, filled, and stored in a dedicated ice cooler. Back in the laboratory, water subsamples were filtered through 25 and $47 \mathrm{~mm}$ diameter Whatman ${ }^{\circledR}$ GF/F filters and immediately stored in the deep freeze for later analysis of suspended particulate material. 
Nitrate + nitrite concentrations $\left(\mathrm{NO}_{3}\right)$ were determined at micromolar concentrations (Raimbault et al. 1990), phosphate concentrations $\left(\mathrm{PO}_{4}\right)$ were determined according to Murphy and Riley (1962), and silicates ( $\mathrm{Si}$ ) were ascertained according to Fanning and Pilson (1973). All these analyses were conducted on a continuous flow Technicon® AutoAnalyzer II. Particulate and dissolved organic matter samples were subject to wet oxidation (Raimbault et al. 1990) and the resulting nitrate (PON and DON) and phosphate (POP and DOP) were analyzed as previously described. Active chlorophyll-a (Chla) and pheopigment (Pheo) concentrations were determined using the in vivo fluorometric technique (Lorenzen 1966).

\section{Data treatment}

Correlation matrix-based PCAs were conducted on the nine sampling datasets of 14 core variables (Sal, Turb, $\mathrm{O} 2 \%, \mathrm{NH}_{4}, \mathrm{NO}_{3}$, $\mathrm{PO}_{4}, \mathrm{Si}, \mathrm{DON}, \mathrm{DOP}, \mathrm{POP}, \mathrm{PON}$, Fluo, Chl-a, Pheo) measured at 34 sampling stations (T02 to T35) and on a similar format matrix averaging data over the whole survey. Albeit of interest for the analysis of each sampling occurrence, the PCA data treatment, when conducted separately on each of the nine individual sampling datasets, allowed for no pertinent intercomparison, due to the absence of a common reference scale. Therefore, spatiotemporal intercomparison was obtained by pairing the averagedsurvey dataset with each individual sampling occurrence dataset and running a PCA, setting the averaged-survey dataset as active (reference) variables and each sampling occurrence dataset as non-active (supplementary) variables (Abdi and Williams 2010). In the present work, the average data matrix (active variables) served as a common referential on which each sampling occasion (non-active variables) could be processed individually hence allowing for an objective multiparametric spatiotemporal intercomparison of hydrological conditions.

\section{Results and discussion}

\section{Climate conditions during the sampling period}

Climate conditions during the October 2008 to July 2010 survey were significantly altered by a period of ENSO instability (Table 1) corresponding to (i) a moderate La Niña period from
November 2008 to March 2009 with a minimum Oceanic Niño Index (ONI) of -0.8 ; (ii) a very short period of normal conditions; (iii) a period of relatively strong El Niño from July 2009 to April 2010 with a maximum ONI of +1.6 ; and finally (iv) a La Niña period starting at the very end of our survey in July 2010. Additionally, the 2009-2010 El Niño was categorized as a Modoki or Central-Equatorial Pacific (CP) El Niño, characterized by lower temperature anomalies than for an EasternEquatorial Pacific (EP) El Niño (Capotondi et al. 2015)

The January 2008 to December 2010 representation of Palizada River daily and monthly averaged flow rate (Fig. 2) evidenced a strong freshwater discharge deficit during the year 2009 , mainly due to low river flow during the rainy and postrainy seasons. Monthly averaged discharge peaked at $220 \mathrm{~m}^{3} \mathrm{~s}^{-1}$ in November 2009, which was far below the 530 and $700 \mathrm{~m}^{3} \mathrm{~s}^{-1}$ maxima recorded in October 2008 and September 2010, respectively. The yearly cumulated Palizada River discharge amounted to 8 and $8.7 \times 10^{9} \mathrm{~m}^{3}$ in 2008 (including contribution from Tropical Storm Marco) and 2010 (no such climatic event but sustained rainfall during the whole rainy period), respectively, whereas in 2009 it amounted to only $4.8 \times 10^{9} \mathrm{~m}^{3}$, corresponding to a deficit of $33 \%$ when compared to the average yearly discharge of $7.2 \times 10^{9} \mathrm{~m}^{3}$ calculated over the 1992 to 2011 time series (Fichez et al. 2017) and a deficit of $39 \%$ and $44 \%$ when compared to the years 2008 and 2010, respectively.

\section{Survey averaged reference}

The PCA primarily yielded an ordination of the main factors accounting for the variability of Terminos Lagoon hydrology (Table 2). The cumulative $70 \%$ variance threshold identifying the main structuring factors (Afifi et al. 2011) was reached or exceeded when combining the first three factors with the exceptions of September 2009, when $77 \%$ of the variance was reached from the first two factors as opposed to March and July 2010 , when the $70 \%$ threshold required a combination of the first four factors.

The first three factors computed from the averaged-survey dataset accounted for $78 \%$ of the variance (Table 2). The biplot representations of Factor 1 against Factor 2 (Fig. 3a) and Factor 3 against Factor 2 (Fig. 3b) showed that Factor 1 accounting for $51 \%$ of variance alone was strongly correlated positively with salinity (0.88) and negatively with most trophic status

Table 1 Oceanic Niño Index -ONI from January 2008 to December 2010. ONI negative values below - 0.5 (La Niña) are shaded in light gray and ONI positive values over +0.5 (El Niño) are shaded in dark gray

\begin{tabular}{c|c|c|c|c|c|c|c|c|c|c|c|c}
\hline Year & D JF & JFM & FMA & MAM & AMJ & MJJ & JJA & JAS & ASO & SON & OND & NDJ \\
\hline 2008 & -1.5 & -1.5 & -1.2 & -0.9 & -0.7 & -0.5 & -0.3 & -0.2 & -0.1 & -0.2 & -0.5 & -0.7 \\
\hline 2009 & -0.8 & -0.7 & -0.5 & -0.2 & 0.2 & 0.4 & 0.5 & 0.6 & 0.8 & 1.1 & 1.4 & 1.6 \\
\hline 2010 & 1.6 & 1.3 & 1.0 & 0.6 & 0.1 & -0.4 & -0.9 & -1.2 & -1.4 & -1.5 & -1.5 & -1.5 \\
\hline 2011 & -1.4 & -1.2 & -0.9 & -0.6 & -0.3 & -0.2 & -0.2 & -0.4 & -0.6 & -0.8 & -1.0 & -1.0 \\
\hline
\end{tabular}


Fig. 2 Temporal variability of Palizada River daily and monthly averaged freshwater flow rates from January 2008 to

March 2011. Sampling campaign occurrences are represented by dark triangles at the base of the $x$ axis. Hydrology data were downloaded on the 28th of April 2014 from the Mexican "Comisión Nacional de Agua" (CONAGUA) online hydrological surveys database. (http://www.conagua.gob.mx/ CONAGUA07/Contenido/ Documentos/Portada $\%$ 20BANDAS.htm)

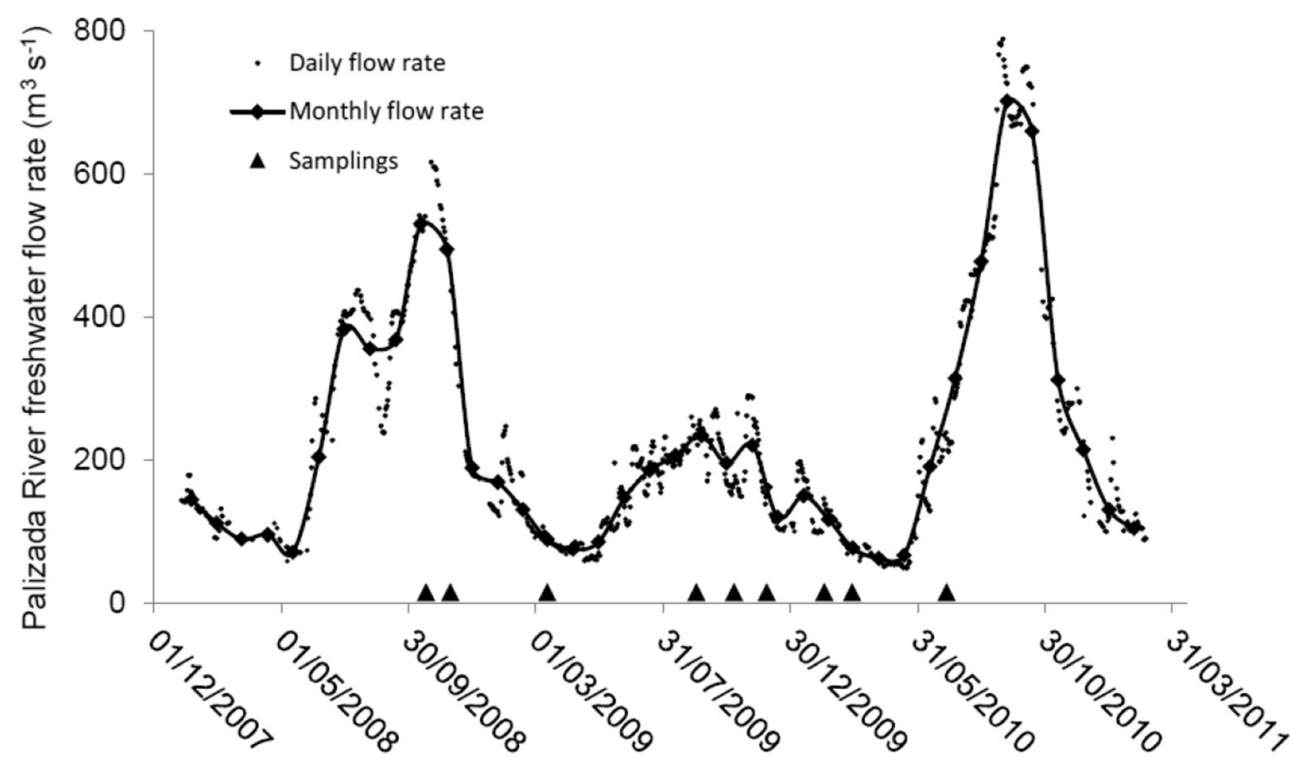

parameters such as POP $(-0.93)$, pheopigments $(-0.92)$, in situ fluorescence $(-0.91)$, chlorophyll-a $(-0.81), \mathrm{NO}_{3}(-$ $0.78), \mathrm{PO}_{4}(-077)$, and $\mathrm{Si}(-0.73)$, or with turbidity $(-0.73)$. Factor 2 accounting for $17 \%$ of variance was mainly positively correlated with DON (0.82), PON (0.63), and DOP (0.50) and negatively correlated with ammonium $(-0.64)$. Factor 3 accounting for $9 \%$ of variance showed a weaker positive correlation with turbidity (0.49) and dissolved oxygen saturation (0.48) and a weaker negative correlation with $\mathrm{Si}(0.43)$.

The biplot representation of cases (i.e., sampling stations) for Factor 1 against Factor 2 (Fig. 3c) and Factor 3 against Factor 2 (Fig. 3d) provided a representation of environmental condition diversity. A strong distribution pattern could be observed on the Factor 1 against Factor 2 biplot that jointly accounted for $68 \%$ of the variance (Fig. 3c). A group of roughly 22 sampling stations located essentially in the central and eastern part of the lagoon was linearly ordinated along a diagonal line stretching from T18 to T35. A second group of ten stations (T02 to T10 and T15) located in the westernmost part of the lagoon diverged from that diagonal line and stretched toward the negative sides of Factors 1 and 2. Stations T16 and T14 stood between those two groups, while a final group of three eastern stations (T30, T29, T34) stretched in parallel to the first diagonal group and on its lower side. The distribution along Factor 1 and Factor 3 was much more homogeneously spread with no strong specific pattern.

The signification of each of the first three PCA factors which cumulatively accounted for $78 \%$ of variance could also be inferred from the study of the few sampling stations that neared the extremity of each axis and/or that significantly departed from the scatterplot nucleus. Stations T06 and T07, located at the mouth of the Palizada River, stood on the negative far end of Factor 1, whereas stations T11, T12, and T20, located leeward of Carmen Island, stood on its positive end. Considering its tight relationship with salinity and trophic status parameters, that first factor of variability related to the estuarine influence essentially driven by the Palizada River that accounted for more than two-thirds of the freshwater inputs to the lagoon. That correlation with the Palizada River influence was further confirmed by the poor correlation with station T34, located directly downstream of Candelaria Estuary. Stations T35, T31, T33, and T32, confined to the easternmost part of the lagoon, stood on the far positive end of Factor 2 corresponding to organic-rich and $\mathrm{NH}_{4}$-depleted waters, whereas nearby station T30 stood on the very opposite end corresponding to water with lower organic load and higher $\mathrm{NH}_{4}$ concentrations. Finally, stations T09 and T29, located in the alignment of the deep channels of Carmen

Table 2 Cumulative percentage of variance corresponding to the first four PCA factors for the nine sampling occasions and for the averaged datasets over the full survey. The dominant structuring factors defined as those cumulatively accounting for 70\% or more (Afifi et al. 2011) are shaded in gray

\begin{tabular}{|l|r|r|r|r|r|r|r|r|r|r|}
\hline $\begin{array}{l}\text { Cumulative } \\
\text { variance \% }\end{array}$ & Oct-08 & Nov-08 & Mar-09 & Sep-09 & Oct-09 & Dec-09 & Feb-10 & Mar-10 & Jul-10 & $\begin{array}{c}\text { Full } \\
\text { survey }\end{array}$ \\
\hline Factor 1 & 38 & 41 & 46 & 51 & 36 & 41 & 32 & 27 & 33 & 51 \\
\hline Factor 2 & 59 & 61 & 64 & 77 & 55 & 58 & 53 & 50 & 54 & 68 \\
\hline Factor 3 & 70 & 71 & 76 & 86 & 73 & 72 & 70 & 67 & 63 & 78 \\
\hline Factor 4 & 78 & 79 & 83 & 91 & 81 & 81 & 77 & 79 & 71 & 84 \\
\hline
\end{tabular}



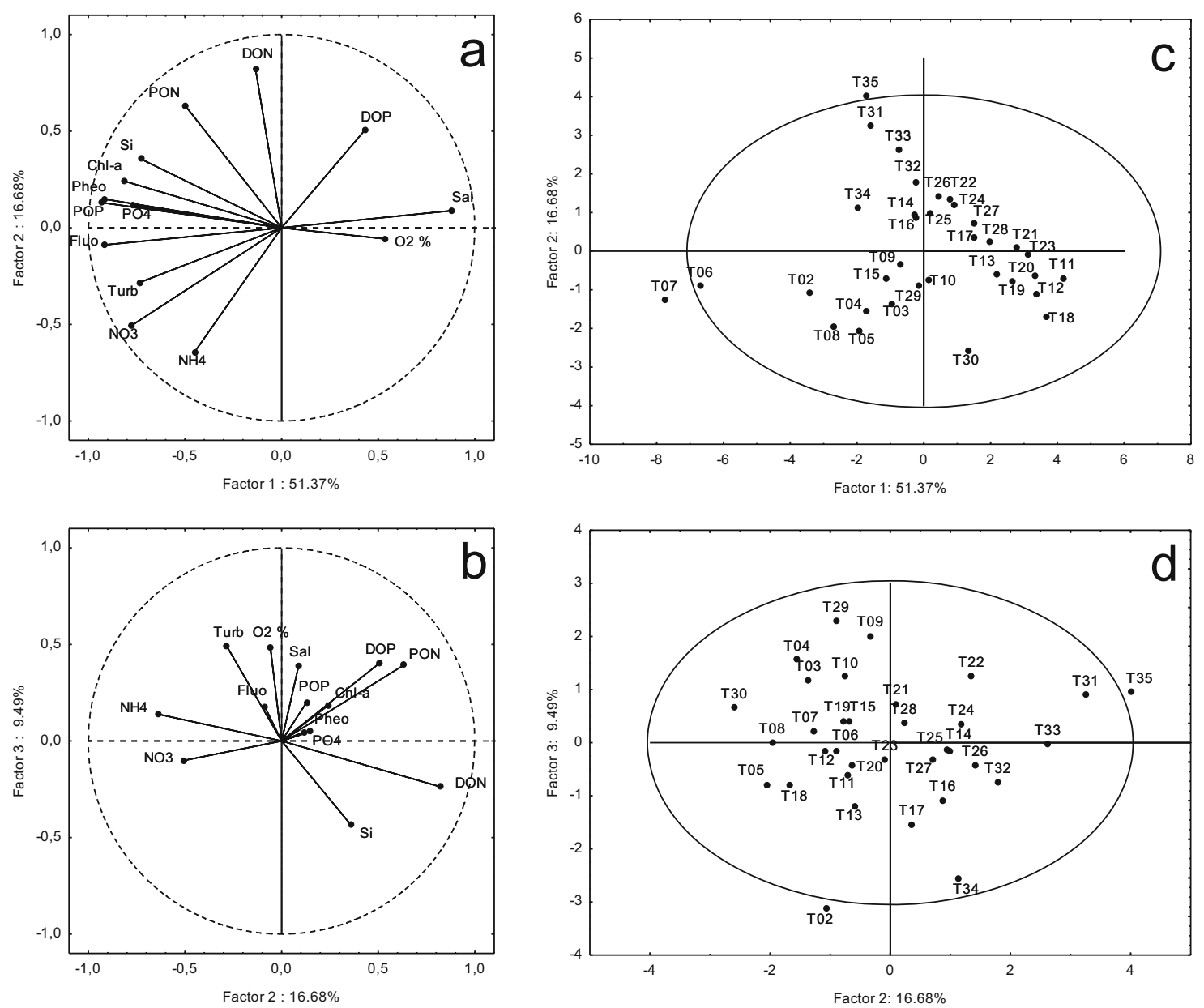

Fig. 3 Biplot representation of the principal component analysis conducted on a reference matrix gathering data averaged over the whole survey ( 34 stations by 14 parameters). Projection of the 14 variables (water parameters) a along factor 1 (51.4\% of variance) showing the essential influence of estuarine (trophic status variables) versus marine (salinity) sources and factor 2 (16.7\% of variance) oppositely linked to DON and $\mathrm{NH}_{4}$; and $\mathbf{b}$ along factors 2 and 3 (9.5\% of variance) oppositely

linked to $\mathrm{O} 2 \%$ and $\mathrm{Si}$. Projection of the 34 cases (stations) along $\mathbf{c}$ factors 1 and 2, and $\mathbf{d}$ factors 2 and 3 . Sal = salinity, Turb = turbidity, $\mathrm{O} 2 \%=$ oxygen saturation percentage, $\mathrm{NH}_{4}=$ ammonia, $\mathrm{NO}_{3}=$ nitrate + nitrite, $\mathrm{PO}_{4}=$ phospates, $\mathrm{Si}=$ silicates, $\mathrm{DON}=$ dissolved organic nitrogen, $\mathrm{DOP}=$ dissolved organic phosphorus, $\mathrm{POP}=$ particulate organic phosphorus, $\mathrm{PON}=$ particulate organic nitrogen, Fluo $=$ in situ chlorophyll-a fluorescence, $\mathrm{Chl}-\mathrm{a}=$ Chlorophyll-a, $\mathrm{Pheo}=$ pheopigments

Inlet and Puerto Real Inlet, respectively, stood on the positive end of Factor 3 correlated with high salinity, oxygen saturation, and turbidity, whereas stations T02 and T34 stood on its negative end.

\section{Spatiotemporal intercomparison}

Results from PCAs using the survey-averaged dataset as active variables and each sampling dataset as non-active (or supplementary) variables allowed to graphically represent the hydrological heterogeneity of each sampling occurrence according to a common referential, hence yielding a statistically supported multiparametric spatiotemporal intercomparison approach. Results from such a combined PCA plotted according to factors 1 and 2 (Fig. 4) and factors 2 and 3 (Fig. 5) showed the most widespread distribution to occur in
October 2008, close to the peak of the rainy season, with coordinates ranging from -25.5 to $-1.3,-5.9$ to 11.5 , and -9.2 to 4.7 for Factors 1, 2, and 3, respectively, when the survey-averaged distribution only ranged from -7.8 to 4.2 , -2.6 to 4.0 , and -3.1 to 2.3 for the same respective factors. Additionally, all coordinates in October 2008 were negative for Factor 1 and mostly positive for Factor 2 or negative for Factor 3. This strong dispersion constricted slightly in November 2008 with values ranging from -14.4 to -4.0 , 3.6 to 7.9 , and -8.1 to 2.5 for Factors 1, 2, and 3, respectively, thus still significantly more widespread than for the surveyaveraged distribution and still exclusively on the negative side for Factor 1 and mainly on the positive side for Factor 2. The scattering then narrowed strongly in March 2009, as the usual dry period conditions prevailed, with coordinate values ranging close to the survey-averaged ones. It then spread slightly 


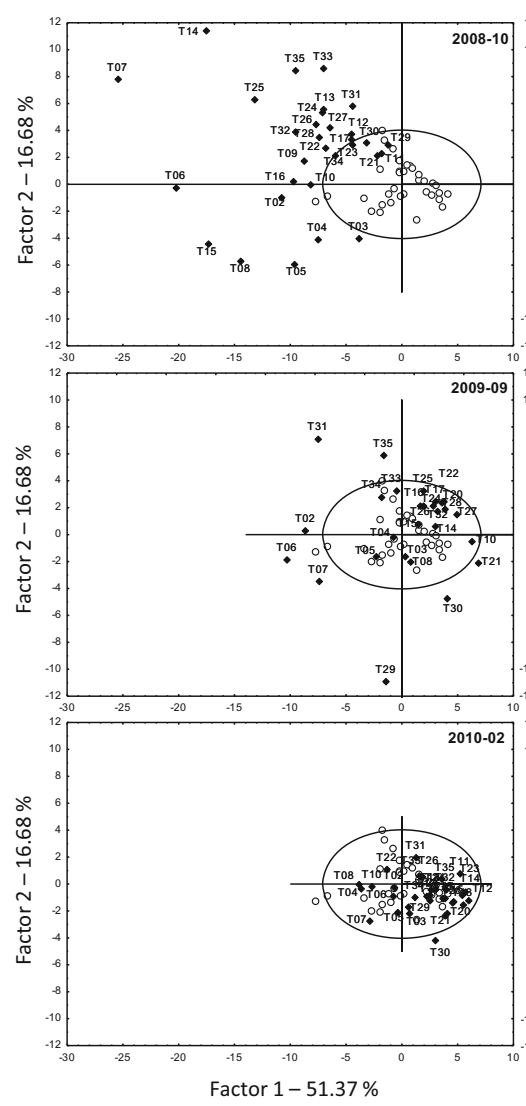

Fig. 4 Principal component analysis of the temporal variability driven by the 14 variables (water parameters) based on the projections along factors 1 and 2 (68\% cumulated variability) of each of the nine sampling
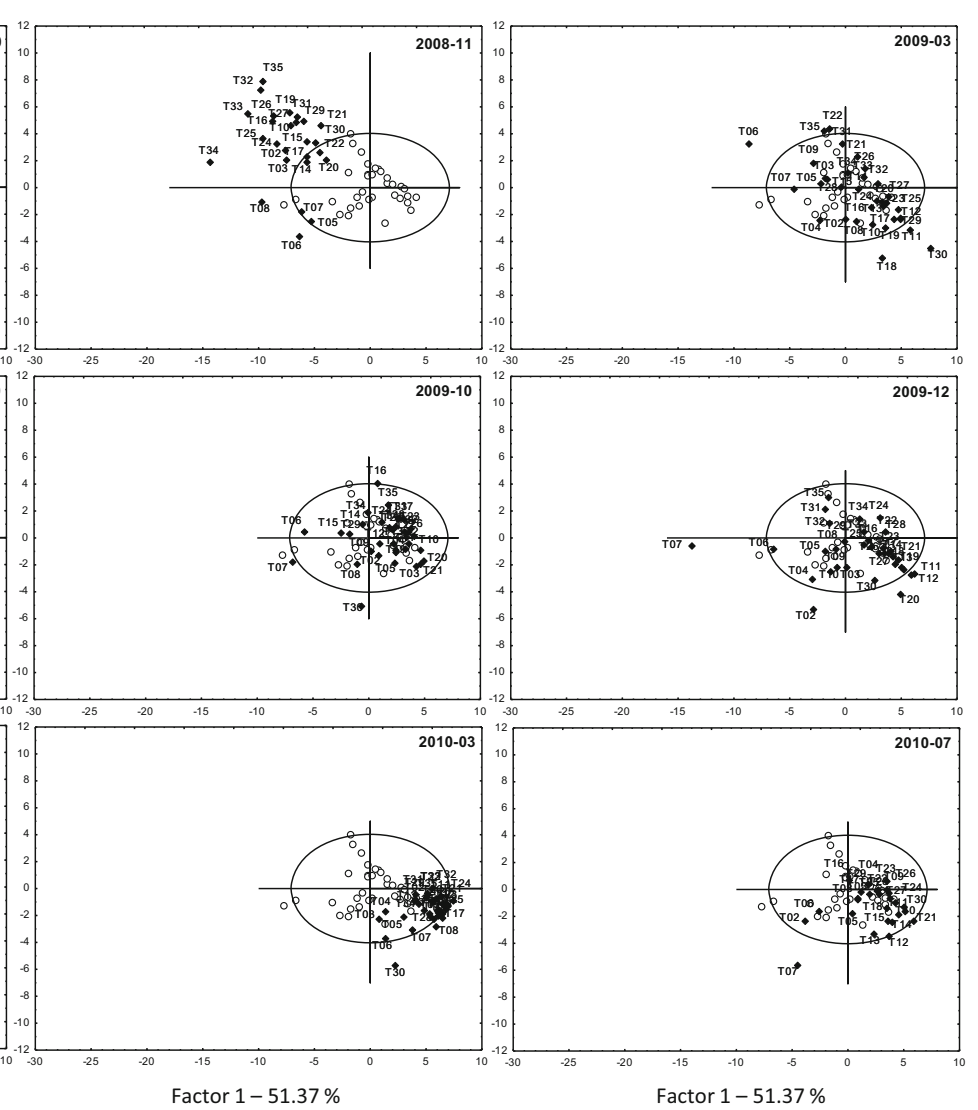

campaigns against the matrix gathering data averaged over the whole survey ( 34 stations by 14 parameters) used as a common reference

variability evidenced a strong partitioning into two main subsystems with: (i) a first western subsystem covering approximately one third of the surface and strongly influenced by the balance between the inputs from the Palizada River and the exchanges through the El Carmen Strait, and (ii) a second subsystem covering approximately the remaining two thirds of the surface and extending over the central and eastern part of the lagoon, and organized along a gradient going from the central part to the easternmost embayment. Such a 1/3 western $2 / 3$ eastern partitioning is consistent with previous works on water budget (Robadue et al. 2004) on the distribution of inorganic nutrients close to the main fresh water input sources (Medina-Gomez et al. 2015) or on the presence of maximal phytoplankton production in the western part due to Palizada River inputs of phosphates and organic matter and strong onsite bacterial mineralization that released additional nutrients (Conan et al. 2017).

Finally, the third major environmental factor correlated with turbidity, oxygen saturation, and salinity related mostly to stations located close to El Carmen and Puerto Real Straits and could be interpreted as being driven by entering wellmixed marine surface waters loaded with particles resuspended from the shallow coastal banks (Contreras Ruiz Esparza together, these two factors which accounted for $68 \%$ 

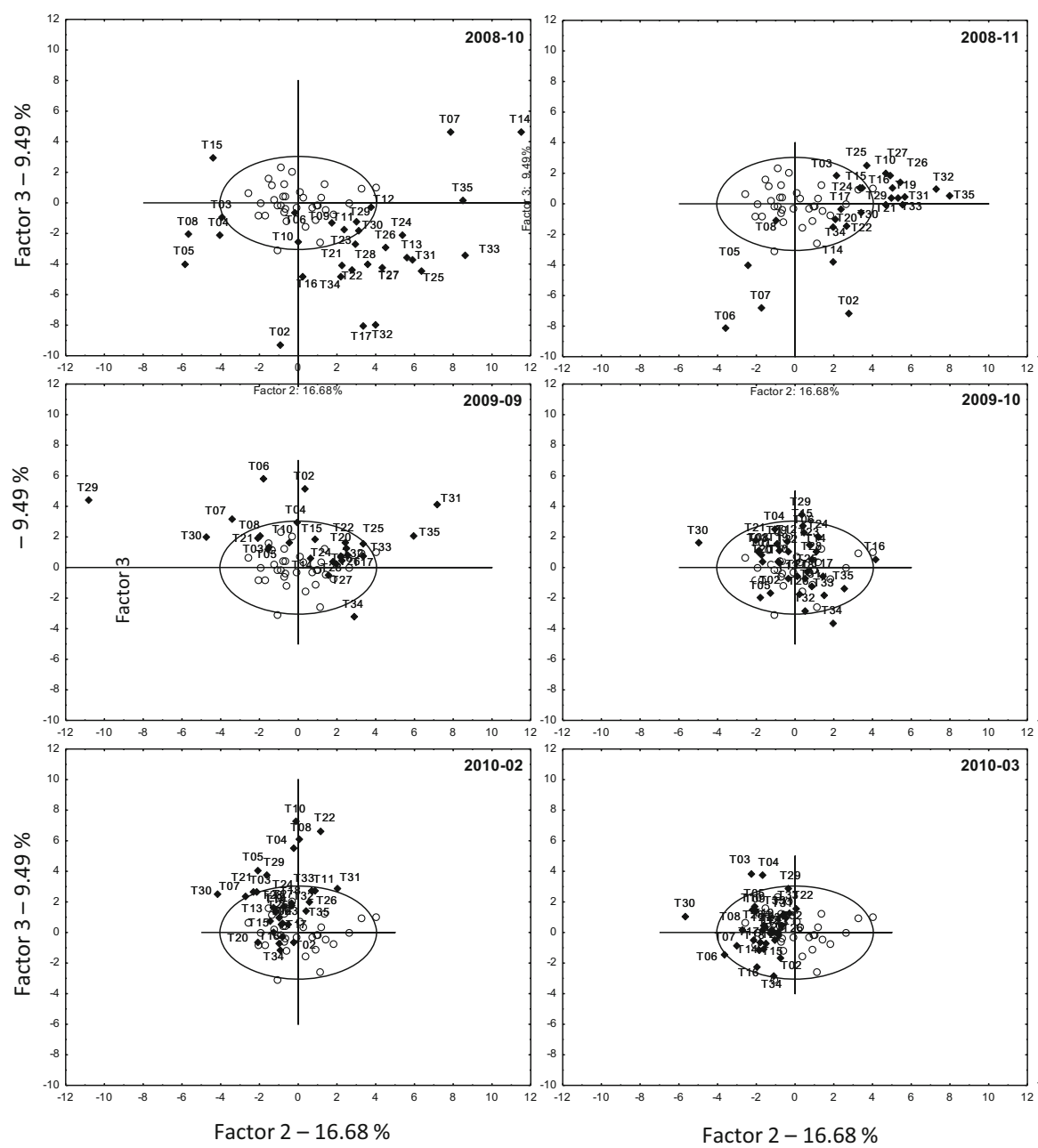

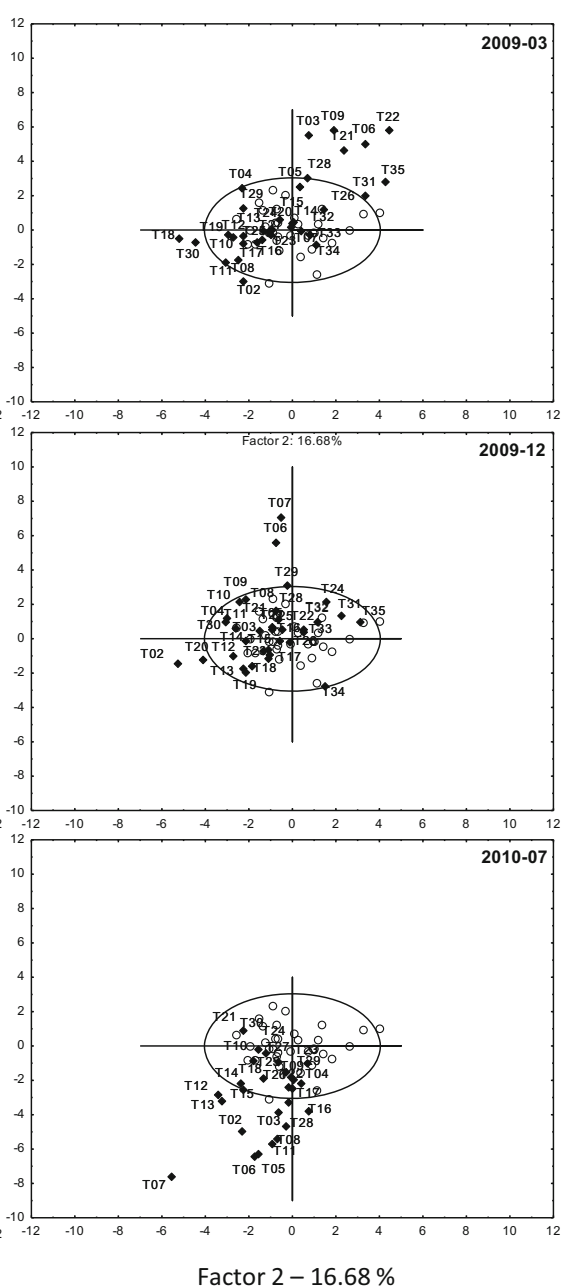

campaigns against the matrix gathering data averaged over the whole survey (34 stations by 14 parameters) used as a common reference
Fig. 5 Principal component analysis of the temporal variability driven by the 14 variables (water parameters) based on the projections along factors 2 and 3 (26\% cumulated variability) of each of the nine sampling et al. 2014). Despite the significant level of turbidity more generally generated by resuspension in such a shallow lagoon system, chlorophyll-a amounted to $70-80 \%$ of the sum of chloropigments in most areas, a ratio range characteristic of relatively productive and non-senescent phytoplankton populations. That apparent paradox between light limitation and active primary production is consistent with recently reported results on phytoplankton dynamics in Terminos Lagoon (Conan et al. 2017) and is not uncommon in very shallow but hydrodynamically active systems where it has been demonstrated that even under very turbid conditions, turbulent water motion may cyclically expose phytoplankton to sufficient surface irradiance to allow for phytoplankton primary production to occur (Fichez et al. 1992).

The dispersion of stations as a function of the PCA factors accounted for the diversity in hydrological conditions, with the more widespread dispersion corresponding to more diverse environmental conditions, and the most compact dispersion corresponding to more homogeneous environmental conditions. The strong variations observed between October 2008 and July 2010 matched with the recorded variability in river discharge driven by the combination of seasonal cycle (rainy versus dry season) and drought period related to the ENSO climate anomaly. The most widespread, and therefore, diverse hydrological conditions were recorded in October 2008, corresponding to a situation typical of the end of the wet season with yearly maximum river discharge. Lesser diverse hydrological conditions were recorded in March 2009, corresponding to a typical end of the dry season with yearly minimum river discharge. From September 2009 to March 2010, the 2009-2010 El Niño-related drought period that severely affected Mexico in July 2009 and which was reported as the driest month since the year 1941 (Baringer et al. 2010) resulted in a drastic decrease in the diversity of hydrological conditions. Even though low water flow rates were very similar in March 2009 and March 2010, the sustained deficit in river discharge during the whole 2010 wet season led to a strong decrease in hydrological condition 
heterogeneity in March 2010 as demonstrated by the drastically less widespread distribution in PCA (Fig. 4a and b) corresponding to a significant loss in the diversity of hydrological conditions. The general shift in salinity nearing marine values and the decrease in nutrients, chloropigments, and organic matter loads (DON, DOP, and PON) resulted in a shift from a system globally classified as brackish and mesotrophic (Herrera-Silveira et al. 2011) to a more saline and oligotrophic one. That shift in trophic status was perfectly summarized by the integrative environmental indicator represented by Chlorophyll-a concentrations (Fichez et al. 2010) which, when averaged over the whole lagoon, decreased from 6.3 to $3.7 \mu \mathrm{g}$ L1 between October 2008 and March 2009, but fell to $0.6 \mu \mathrm{g} \mathrm{L}^{-1}$ in March 2010, thus showing the 2009-2010 drought-related deficit in river inputs to result in a sixfold decrease in phytoplankton stock. This rapid and significant trophic impoverishment proved that the high trophic status of Terminos Lagoon strongly depends on river-borne new nutrient inputs, the input of recycled nutrients from the sediment reservoir being unable to sustain such a high trophic status, even over a relatively short duration. The relative imbalance between the respective influence of river-borne and sediment nutrient sources on the biogeochemical functioning of the Terminos Lagoon converged with previous results showing nitrogen turnover times to range from less than 1 day for inorganic nitrogen in the water column to over 3000 days for sedimentary organic nitrogen (Hopkinson et al. 1988).

\section{Short- to long-term potential consequences}

The strong influence of river inputs on the trophic status and hydrological diversity evidenced in the present work was consistent with the Flood Pulse Concept (FPC) which defines flood pulse as the major driving force in wetland systems (Junk and Wantzen 2004). This concept was recently linked in Terminos Lagoon to an adaptive diversification in resource use by consumers (Sepúlveda-Lozada et al. 2017), with periods of high river inputs resulting in higher trophic diversification and lower trophic redundancy, and conversely. Shifts in hydrological diversity and trophic status leading to a strong variability in food supply have been seen to impact entire communities in terms of density, diversity, and physiological state (Wantzen et al. 2002; Junk and Wantzen 2004; Abrantes et al. 2014). The homogenization of hydrological conditions and impoverishment in trophic status caused by the decrease in river inputs that we evidenced in Terminos Lagoon will ineluctably have an impact on the ecological balance of the Terminos Lagoon. Shift in hydrological conditions from hypohaline to euhaline/hyperhaline status in Terminos Lagoon has already been held responsible for having detrimental impacts on the food web (Abascal-Monroy et al. 2015), on juvenile development stages of exploited species, and subsequently on the stock of living resources in the surrounding coastal system of the Gulf of Mexico (Ramos Miranda et al. 2005; Sosa López et al. 2005; Villéger et al. 2010; Sirot et al. 2015). However, our work demonstrated that the increase in salinity concurred with a loss in hydrological condition diversity and a decrease in trophic status that offer a much more consistent explanation for the loss of functional diversity and biotic homogenization in the fish community of Terminos lagoon reported by those authors. Moreover, Conan et al. (2017) characterized the Terminos pelagic ecosystem as a "nitrogen assimilator" because of its relatively high internal production and weak autochthonous exportation to the Gulf of Mexico. These authors also concluded that "bottom-up" control was dominant for microbial productivity and that the heterogeneity in phytoplankton and free-living prokaryote distribution in the lagoon was largely explained by nitrogen to phosphorus stoichiometry. In such a context, and as already reported for many rivers (Turner et al. 2003; Seitzinger et al. 2010), expected decreases in rainfall and river discharge together with modification in land use will most certainly modify the $\mathrm{N}$ versus $\mathrm{P}$ balance of nutrient inputs to Terminos Lagoon, hence potentially further impacting its ecosystem structure and functioning.

Even though the inherent variability of transitional systems corresponding to their "buffer capacity" (Carpenter et al. 2001) has been alternatively hypothesized as the most likely driver of present shifts in fish population in Terminos Lagoon (Fichez et al. 2017), predictive climate scenarios strongly suggest that the Terminos Lagoon system might face a future long-term change in its salinity balance and related hydrological conditions and trophic status. While modeling approaches based on various IPCC emission scenarios do not foresee change in rainfall for the next decades in the Mexico-Central America region, a decline by $5 \%$ to $30 \%$ is expected during the second part of the century (Sáenz-Romero et al. 2010; Met Office 2011; Biasutti et al. 2012; Hidalgo et al. 2013). For example, if no significant precipitation change is expected during the first half of the twenty-first century, precipitation decline is expected in its second half with a decrease of $7 \%$ in Guatemala and 10 to $13 \%$ in Belize under IPCC emission scenario B2, and of 27 to $32 \%$ in Belize and Guatemala under scenario A2 with an averaged reduction of $28 \%$ at the regional scale (Barcena et al. 2010). Similarly, based on various emission scenarios, significant reductions in precipitation (as much as 5-10\%) and runoff (as much as 10-30\%) is anticipated for the 2050-2099 period in northern Central America (Hidalgo et al. 2013) with a projected decrease in precipitation by $13 \%$ in southern Mexico in summer and slight increase in autumn (Colorado-Ruiz et al. 2018). Those numbers come close to the $33 \%$ deficit in river discharge we recorded during the 2009 drought when compared to the yearly river discharge averaged over the 1992-2011 time period, and certain authors even claim that an $80 \%$ decrease in freshwater discharge from the Usumacinta-Grijalva River catchment may be expected 
(Kemp et al. 2016). In Terminos Lagoon as well as in most Central America coastal lagoons, such alleged long-term decrease in rainfall and river discharge will thus result in a longterm shift toward higher salinity, lower diversity in hydrological conditions and lower trophic status of comparable or even greater magnitude than the one we evidenced, with corollary impacts on biodiversity and productivity.

\section{Conclusion}

The present study has allowed to mathematically define and represent the spatiotemporal variability of hydrological conditions in Terminos Lagoon yielding a synthetic vision of the global organization of water masses that clearly demonstrated a strong variability which is mainly driven by river inputs. The proposed approach provided evidence of the drastic impact of the 2009-2010 El Niño-related drought period on the salinity and trophic status of the lagoon, showing its sensitivity to climatic events. The occurrence of a 6-month-long severe deficit in river inputs due to that drought was seen to have resulted in a strong decrease in the heterogeneity/diversity in hydrological conditions, with an increase in salinity and a significant trophic status shift from mesotrophic to oligotrophic. As climate change scenarios converge to significant decreases in rainfall in the region, such a relationship between river inputs, hydrological diversity, and trophic status means that the whole trophic network and living resources will be impacted. Such potential impacts on the diversity of environmental conditions must be factored into environmental management plans in order to ensure the sustainability of the current status of Terminos Lagoon as a protected area and as a living resource reservoir for the whole region. Beyond its application to the specific case of Terminos Lagoon, the proposed spatiotemporal intercomparison approach based on the combination using average database PCA coordinates as a reference matrix could be more widely applied in order to efficiently valorise multiparametric datasets.

Acknowledgments We are especially thankful to Instituto de Ciencias del Mar y Limnologia, Universidad Nacional Autónoma de México (ICMLUNAM) for providing access to their field station in Ciudad del Carmen, to the French Research Vessel Antea, and to the Mexican Comisión Nacional del Agua (CONAGUA) for providing online access to longterm series of river discharges and precipitation through their databases "Banco Nacional de Datos de Aguas Superficiales" (BANDAS) and "Base de datos climatologica nacional - Sistema CLICOM", respectively.

Funding information This work was supported by the Institut de Recherche pour le Développement (IRD), the Centre National de la Recherche Scientifique (CNRS), the Université de Lille, the Universidad Autónoma Metropolitana-Iztapalapa (UAM-I), the French National Program Ecosphère Continentale et Côtière - Dynamique et Réactivité des Interfaces Littorales (EC2CO-DRIL), and the European FEDER Fund under project 1166-39417.

\section{References}

Abascal-Monroy IM, Zetina-Rejon MJ, Escobar-Toledo F, Lopez-Ibarra GA, Sosa-Lopez A, Tripp-Valdez A (2015) Functional and structural food web comparison of Terminos Lagoon, Mexico in three periods (1980, 1998, and 2011). Estuar Coasts 39:1282-1293. https:// doi.org/10.1007/s12237-015-0054-0

Abdi H, Williams LJ (2010) Principal component analysis. WIREs Comp Stat 2:433-459. https://doi.org/10.1002/wics.101

Abrantes KG, Barnett A, Bouillon S (2014) Stable isotope-based community metrics as a tool to identify patterns in food web structure in east African estuaries. Funct Ecol 28:270-282. https://doi.org/10. 1111/1365-2435.12155

Afifi A, May S, Clark VA (2011) Practical multivariate analysis, fifth edition. Chapman and Hall/CRC, Boca Raton

Barcena A, Prado A, Beteta H, Samaniego JL, Lennox J (2010) The economics of climate change in Central America. Summary 2010. UN-CEPAL report, $\mathrm{p}$ 25-26

Baringer MO, Arndt DS, Johnson MR (2010) State of the climate in 2009. Bull Am Meteorol Soc 91(7):S142-S143. https://doi.org/10. 1175/BAMS-91-7-StateoftheClimate

Biasutti M, Sobel AH, Camargo SJ, Creyts TT (2012) Projected changes in the physical climate of the Gulf coast and Caribbean. Clim Chang 112:819-845. https://doi.org/10.1007/s10584-011-0254-y

Capotondi A, Wittenberg AT, Newman M, Di Lorenzo E, Yu JY, Braconnot P, Cole J, Dewitte B, Giese B, Guilyardi E, Jin FF, Karnauskas K, Kirtman B, Lee T, Schneider N, Xue Y, Yeh SW (2015) Understanding ENSO Diversity. Bull Am Meteorol Soc 96: 921-938. https://doi.org/10.1175/BAMS-D-13-00117.1

Carpenter S, Walker B, Anderies JM, Abel N (2001) From metaphor to measurement: resilience of what to what? Ecosystems 4:765-781. https://doi.org/10.1007/s10021-001-0045-9

Colorado-Ruiz G, Cavazos T, Salinas JA, De Grau P, Ayala R (2018) Climate change projections from Coupled Model Intercomparison Project phase 5 multi-model weighted ensembles for Mexico, the North American monsoon, and the mid-summer drought region. Int J Climatol 38:5699-5716. https://doi.org/10.1002/joc.5773

Conan P, Agab M, Calva Benítez LG, Chifflet S, Douillet P, Dussud C, Fichez R, Grenz C, Gutierrez Mendieta F, Origel-Moreno M, PujoPay M, Rodríguez-Blanco A, Sauret C, Severin T, Tedetti M, Torres Alvarado R, Ghiglione J-F (2017) Combining biogeochemical characterisation and microbial biomass and activities to assess pelagic cycling in a large and shallow tropical lagoon (Terminos Lagoon, Mexico). Biogeosciences 14:959-975. https://doi.org/10.1016/j. crte.2017.09.016

Contreras Ruiz Esparza A, Douillet P, Zavala-Hidalgo J (2014) Tidal dynamics of the Terminos lagoon, Mexico: observations and 3D numerical modelling. Ocean Dyn 64:1349-1371. https://doi.org/ 10.1007/s10236-014-0752-3

David LT (1999) Laguna de Términos, Campeche. In: Smith SV, Marshall Crossland JI, Crossland CJ (eds) Mexican and central American coastal lagoon systems: carbon, nitrogen and phosphorus fluxes, LOICZ reports and studies $\mathrm{N}^{\circ} 13$, LOICZ international project office. Texel, The Netherlands, pp 9-15

David LT, Kjerfve B (1998) Tides and Currents in a Two-Inlet Coastal Lagoon: Laguna de Términos, México. Cont Shelf Res 18:10571079. https://doi.org/10.1016/S0278-4343(98)00033-8

Elliott M, McLusky DS (2002) The need for definitions in understanding estuaries. Estuar Coast Shelf Sci 55:815-827. https://doi.org/10. 1006/ecss.2002.1031

Espinal JC, Salles PAA, Morán DK (2007) Storm surge and sediment process owing to hurricane Isidore in Terminos Lagoon, Campeche. In: Kraus NC, Dean Rosati J (eds) Coastal sediments '07: proceedings of the sixth international symposium on coastal engineering and 
science of coastal sediment process, American Society of Civil Engineers. Reston, USA, pp 996-1007

Fanning KA, Pilson ME (1973) On the spectrophotometric determination of dissolved silica in natural waters. Anal Chem 45:136-140. https:// doi.org/10.1021/ac60323a021

Fichez R, Jickells TD, Edmunds HM (1992) Algal blooms in high turbidity, a result of the conflicting consequences of turbulence on nutrient cycling in a shallow water estuary. Estuar Coast Shelf Sci 35:577-592. https://doi.org/10.1016/S0272-7714(05)80040-X

Fichez R, Archundia D, Grenz C, Douillet P, Gutiérrez Mendieta F, Origel Moreno M, Denis L, Contreras Ruiz Esparza A, Zavala-Hidalgo J (2017) Global climate change and local watershed management as potential drivers of salinity variation in a tropical coastal lagoon (Laguna de Terminos, Mexico). Aquat Sci 79:219-230. https://doi. org/10.1007/s00027-016-0492-1

Fichez R, Chifflet S, Douillet P, Gérard P, Gutierrez F, Jouon A, Ouillon S, Grenz C (2010) Biogeochemical typology and temporal variability of lagoon waters in a coral reef ecosystem subject to terrigeneous and anthropogenic inputs (New Caledonia). Mar Pollut Bull 61: 309-322. https://doi.org/10.1016/j.marpolbul.2010.06.021

Furnas M (2003) Catchments and corals: terrestrial runoff to the great barrier reef. Australian Institute of Marine Science and CRC Reef Research Centre, Townsville, p 334

García-Ríos V, Alpuche-Gual L, Herrera-Silveira J, Montero-Muñoz J, Morales-Ojeda S, Pech D, Cepeda-González MF, Zapata-Pérez O, Gold-Bouchot G (2013) Towards a coastal condition assessment and monitoring of the Gulf of Mexico Large Marine Ecosystem (GoM LME): Terminos Lagoon pilot site. Environm Dev 7:72-79. https:// doi.org/10.1016/j.envdev.2013.04.007

Giorgi F (2006) Climate change hot-spots. Geophys Res Lett 33:L08707. https://doi.org/10.1029/2006GL025734

Grenz C, Fichez R, Alvarez Silva C, Calva Benitez L, Conan P, Contreras Ruiz Esparza A, Denis L, Díaz Ruiz S, Douillet P, Gallegos Martinez M, Ghiglione J-F, Gutiérrez Mendieta F, Origel-Moreno M, Marquez Garcia A, Muñoz Caravaca A, Pujo-Pay M, Torres Alvarado R, Zavala-Hidalgo J (2017) Benthic ecology of tropical coastal lagoons: environmental changes over the last decades in the Terminos Lagoon, Mexico. Compt Rendus Geosci 349:319-329. https://doi.org/10.1016/j.crte.2017.09.016

Haynes D, Brodie J, Christie C, Devlin M, Michalek-Wagner K, Morris S, Ramsay M, Storrie J, Waterhouse J, Yorkston H (2001) Great Barrier Reef water quality: current issues. Great Barrier Reef Marine Park Authority, Townsville, Australia

Herrera-Silveira JA, Morales-Ojeda SM, Cortes-Balan T O (2011) Eutrofización en los ecosistemas costeros Del Golfo de México: V.1. SEMARNAT-NOAA-GEF-UNIDO. 88. https://fr.scribd.com/ document/356698755/Eutrofizacion-en-Ecosistemas-costerosGoM-JHerrera-pdf Accessed date September 17, 2015

Hidalgo HG, Amador JA, Alfaro EJ, Quesada B (2013) Hydrological climate change projections for Central America. J Hydrol 495:94 112. https://doi.org/10.1016/j.jhydrol.2013.05.004

Holmes RM, Aminot A, Kérouel R, Bethanie A, Hooher A, Peterson BJ (1999) A simple and precise method for measuring ammonium in marine and freshwater ecosystems. Can J Aquat Sci 56:1801-1808. https://doi.org/10.1139/f99-128

Hopkinson CS, Kipp SJ, Stevenson JC (1988) Nitrogen pools and turnover times in a tropical seagrass system, Terminos Lagoon. In Ecology of Coastal ecosystem in the southern Gulf of Mexico: The Terminos lagoon Region, eds Yanez-Arancibia A. and Day J.W., Inst. Cien. Del Mar y Limnol. UNAM, Coast. Ecol. Inst. LSU Editorial Universitaria, Mexico DF. Chap. 9, p. 171-180

Hudson PF, Hendrickson DA, Benke AC, Varela-Romero A, RodilesHernández R, Minckley WL (2005) Rivers of Mexico. In: Benke AC, Cushing CE (eds) Rivers of North America, Elsevier Academic Press, pp 1030-1084
Junk WJ, Wantzen KM (2004) The flood pulse concept: new aspects, approaches and applications-an update. In: Welcomme RL, Petr AT (eds) Proceedings of the Second International Symposium on the Management of Large Rivers for Fisheries, II edn. FAO Regional Office for Asia and the Pacific, Bangkok, pp 117-140

Kemp GP, Day JW, Yáñez-Arancibia A, Peyronnin NS (2016) Can continental Shelf River plumes in the northern and southern Gulf of Mexico promote ecological resilience in a time of climate change? Water 8(3):83. https://doi.org/10.3390/w8030083

Kérouel R, Aminot A (1997) Fluorometric determination of ammonia in sea and estuarine waters by direct segmented flow analysis. Mar Chem 57:265-275. https://doi.org/10.1016/S03044203(97)00040-6

Larned ST (1998) Nitrogen- versus phosphorus-limited growth and sources of nutrients for coral reef macroalgae. Mar Biol 132:409 421. https://doi.org/10.1007/s002270050407

Liston P, Furnas MJ, Mitchell AW, Drew EA (1992) Local and mesoscale variability of surface water temperature and chlorophyll in the northern Great Barrier Reef. Aust Cont Shelf Res 12:907-921. https://doi. org/10.1016/0278-4343(92)90051-K

Lorenzen CJ (1966) A method for the continuous measurement of in vivo chlorophyll concentration. Deep-Sea Res 13:223-227. https://doi. org/10.1016/0011-7471(66)91102-8

Lucena-Moya P, Gómez-Rodríguez C, Pardo I (2012) Spatio-temporal variability in water chemistry of Mediterranean coastal lagoons and its management implications. Wetlands 32:1033-1045. https:// doi.org/10.1007/s13157-012-0334-4

Magrin G, Gay García C, Cruz Choque D, Giménez JC, Moreno AR, Nagy GJ, Nobre C, Villamizar A (2007) Latin America. Climate change 2007: impacts, adaptation and vulnerability. Contribution of working group II to the fourth assessment report of the intergovernmental panel on climate change. In: Parry ML, Canziani OF, Palutikof JP, van der Linden PJ, Hanson CE (eds) . Cambridge University Press, Cambridge, UK, pp 581-615

McLusky DS, Elliott M (2007) Transitional waters: a new approach, semantics or just muddying the waters? Estuar Coast Shelf Sci 71: 359-363. https://doi.org/10.1016/j.ecss.2006.08.025

Medina-Gomez I, Villalobos-Zapata GJ, Herrera-Silveira JA (2015) Spatial and temporal hydrological variations in the inner estuaries of a large coastal lagoon of the southern Gulf of Mexico. J Coast Res 31:1429-1438. https://doi.org/10.2112/ JCOASTRES-D-13-00226.1

Met Office (2011) Climate: observations, projections and impacts. Met Office, Exeter, UK https://www.metoffice.gov.uk/climateguide/science/uk/obs-projections-impacts (last accessed on January 30 2015)

Murphy P, Riley JP (1962) A modified single solution method for the determination of phosphate in natural waters. Anal Chim Acta 27: 31-36. https://doi.org/10.1016/S0003-2670(00)88444-5

Muslim I, Jones G (2003) The seasonal variation of dissolved nutrients, chlorophyll a and suspended sediments at Nelly Bay, Magnetic Island. Estuar Coast Shelf Sci 57:445-455. https://doi.org/10.1016/ S0272-7714(02)00373-6

Ouillon S, Douillet P, Andrefouet S (2004) Coupling satellite data with in situ measurements and numerical modeling to study fine suspendedsediment transport: a study for the lagoon of New Caledonia. Coral Reefs 23:109-122. https://doi.org/10.1007/s00338-003-0352-z

Poikane S, Zampoukas N, Borja A, Davies SP, van de Bund W, Birk S (2014) Intercalibration of aquatic ecological assessment methods in the European Union: lessons learned and way forward. Environ Sci Pol 44:237-246. https://doi.org/10.1016/j.envsci.2014.08.006

Rahmstorf S (2012) Sea-level rise: towards understanding local vulnerability. Environ Res Lett 7:1-3. https://doi.org/10.1088/1748-9326/7/ 2/021001

Raimbault P, Slawyk G, Coste B, Fry J (1990) Feasibility of measuring an automated colorimetric procedure for the determination of seawater 
nitrate in the 0 to $100 \mathrm{nM}$ range: examples from field and culture. Mar Biol 104:347-351. https://doi.org/10.1007/BF01313277

Ramos Miranda J, Mouillot D, Flores Hernandez D (2005) Changes in four complementary facets of fish diversity in a tropical coastal lagoon after 18 years: a functional interpretation. Mar Ecol Prog Ser 304:1-13. https://doi.org/10.3354/meps304001

Robadue D Jr, Oczkowski A, Calderon R, Bach L, Cepeda MF (2004) Characterization of the region of the Terminos Lagoon: Campeche, Mexico. PlusDraft 1 Site Profile. Draft for discussion. The Nature Conservancy, Corpus Christi, Texas, USA. http://www.crc.uri.edu/ download/23s_L1Profile_Draft_Terminos_2004.pdf Accessed date August 6, 2007

Sáenz-Romero C, Rehfeldt GE, Crookston NL, Duval P, St-Amand R, Beaulieu J, Richardson BA (2010) Spline models of contemporary, 2030, 2060 and 2090 climates for Mexico and their use in understanding climate-change impacts on the vegetation. Clim Chang 102:595-623. https://doi.org/10.1007/s10584-009-9753-5

Seitzinger SP, Mayorga E, Bouwman AF, Kroeze C, Beusen AHW, Billen G, Van Drecht G, Dumont E, Fekete BM, Garnier J, Harrison JA (2010) Global river nutrient export: a scenario analysis of past and future trends. Glob Biogeochem Cycles 24:GB0A08. https://doi.org/10.1029/2009GB003587

Sepúlveda-Lozada A, Saint-Paul U, Mendoza-Carranza M, Wolff M, Yáñez-Arancibia A (2017) Flood pulse induced changes in isotopic niche and resource utilization of consumers in a Mexican floodplain system. Aquat Sci 79(3):597-616. https://doi.org/10.1007/s00027017-0520-9

Shin JY, Artigas F, Hobble C, Lee Y-L (2013) Assessment of anthropogenic influences on surface water quality in urban estuary, northern New Jersey: multivariate approach. Environ Monit Assess 185: 2777-2794. https://doi.org/10.1007/s10661-012-2748-0
Sirot C, Villéger S, Mouillot D, Darnaude AM, Ramos-Miranda J, FloresHernandez D, Panfili J (2015) Combinations of biological attributes predict temporal dynamics of fish species in response to environmental changes. Ecol Indic 48:147-156. https://doi.org/10.1016/j. ecolind.2014.07.038

Sosa López A, Mouillot D, Do Chi T, Ramos Miranda J (2005) Ecological indicators based on fish biomass distribution along trophic levels: an application to the Terminos coastal lagoon, Mexico. ICES J Mar Sci 62:453-458

Turner RE, Rabalais NN, Justic' D, Dortch Q (2003) Global patterns of dissolved N, P and Si in large rivers. Biogeochemistry 64:297-317. https://doi.org/10.1023/A:1024960007569

Vázquez-González C, Fermán-Almada J-L, Moreno-Casasola P, Espejel I (2014) Scenarios of vulnerability in coastal municipalities of tropical Mexico: an analysis of wetland land use. Ocean Coast Manag 89: 11-19. https://doi.org/10.1016/j.ocecoaman.2013.12.004

Villéger S, Ramos Miranda J, Flores Hernandez D, Mouillot D (2010) Contrasting changes in taxonomic vs functional diversity of tropical fish assemblages after habitat degradation. Ecol Appl 20:15121522. https://doi.org/10.1890/09-1310.1

Wantzen KM, de Arruda F, Voss M, Boriss H, Junk WJ (2002) Seasonal isotopic shifts in fish of the Pantanal wetland, Brazil. Aquat Sci 64: 239-251. https://doi.org/10.1007/PL00013196

Zeng L, Li D (2015) Development of in situ sensors for chlorophyll concentration measurement. J Sensors 903509:16. https://doi.org/ $10.1155 / 2015 / 903509$

\section{Affiliations}

\section{Renaud Fichez ${ }^{1}$ (D) $\cdot$ Carlos Linares $^{2} \cdot$ Sandrine Chifflet $^{1} \cdot$ Pascal Conan $^{3} \cdot$ Adolfo Contreras Ruiz Esparza $^{4}$. Lionel Denis ${ }^{5}$. Pascal Douillet ${ }^{1}$. Christian Grenz ${ }^{1}$ • Jean-François Ghiglione ${ }^{3}$ • Francisco Gutiérrez Mendieta ${ }^{6}$. Montserrat Origel-Moreno ${ }^{1}$ - Alain Muñoz Caravaca ${ }^{7}$ - Mireille Pujo-Pay ${ }^{3} \cdot$ Jorge Zavala-Hidalgo $^{4}$}

1 Université de Toulon, CNRS/INSU, IRD, Mediterranean Institute of Oceanography MIO UM 110, Aix-Marseille Université, Campus Universitaire de Luminy, 13288 Marseille, France

2 Université de Sherbrooke, 2500 boulevard de l'Université, Sherbrooke, Québec J1K 2R1, Canada

3 CNRS, UMR LOMIC 7621, Laboratoire ARAGO, UPMC Université Pierre et Marie Curie, Avenue Fontaulé, BP44, F-66650 Banyuls-sur-Mer, France
4

Centro de Ciencias de la Atmósfera, Universidad Nacional Autónoma de México, México D.F., Mexico

5 Laboratoire d'Océanologie et de Géosciences (LOG) UM 8187, Université des Sciences et Technologies de Lille, Wimereux, France

6 Departamento de Hidrobiologia, Universidad Autonoma Metropolitana, Av. San Rafael Atlixco 186, Col. Vicentina, Iztapalapa, C.P. 09340 México D.F., Mexico

7 Centro de Estudios Ambientales de Cienfuegos, Carretera Castillo de Jagua, Km 1 1⁄2, AP. 5, CP 59350 Cienfuegos, Cuba 